\title{
Acidaminococcus intestini sp. nov., isolated from human clinical samples
}

\author{
Estelle Jumas-Bilak, ${ }^{1}$ Jean-Philippe Carlier, ${ }^{2}$ Hélène Jean-Pierre, ${ }^{3}$ \\ Francine Mory, ${ }^{4}$ Corinne Teyssier, ${ }^{1}$ Bernard Gay, ${ }^{3}$ Josiane Campos ${ }^{3}$ \\ and Hélène Marchandin ${ }^{3}$ \\ ${ }^{1}$ Université Montpellier 1, Faculté de Pharmacie, Laboratoire de Bactériologie-Virologie, 15 Avenue \\ Charles Flahault, BP 14491, 34060 Montpellier Cedex 5, France \\ ${ }^{2}$ Institut Pasteur, Centre National de Référence des Bactéries Anaérobies et du Botulisme, 25 rue \\ du Dr Roux, 75724 Paris Cedex 15, France \\ ${ }^{3}$ Centre Hospitalier et Universitaire de Montpellier, Hôpital Arnaud de Villeneuve, Laboratoire de \\ Bactériologie, 371 Avenue du Doyen Gaston Giraud, 34295 Montpellier Cedex 5, France
}

Correspondence

Hélène Marchandin

h-marchandin@chu-montpellier.fr
${ }^{4}$ Centre Hospitalier et Universitaire de Nancy, Hôpital Central, Laboratoire de Bactériologie, 29 avenue du Maréchal de Lattre de Tassigny, 54035 Nancy Cedex, France

\begin{abstract}
Eleven strains of a hitherto unknown, Gram-negative, anaerobic coccus were recovered from various human clinical samples of patients hospitalized in two geographically distant French hospitals. These strains displayed the morphology and growth characteristics of those related to the genus Acidaminococcus. The clinical isolates shared at least 99.9 and $99.7 \%$ of their nucleotide positions in the $16 \mathrm{~S}$ and $23 \mathrm{~S}$ rRNA gene sequences, respectively. They displayed 95.6 and $88.9 \% 16 \mathrm{~S}$ and $23 \mathrm{~S}$ rRNA gene sequence similarities, respectively, with Acidaminococcus fermentans. The $16 \mathrm{~S}$ rRNA-based phylogeny revealed that all the clinical isolates grouped in a statistically well supported cluster separate from $A$. fermentans. Enzymic activity profiles as well as metabolic end product patterns, including propionic acid production, differentiated the novel bacteria from A. fermentans. Finally, phenotypic, genotypic and phylogenetic data, including large-scale chromosome structure and DNA G+C content, supported the proposal of a novel species of the genus Acidaminococcus, for which the name Acidaminococcus intestini sp. nov. is proposed. The type strain is ADV $255.99^{\top}$ (=AIP $283.01^{\top}=$ CIP $108586^{\top}=$ CCUG $50930^{\top}$ ).
\end{abstract}

The genus Acidaminococcus was erected by Rogosa (1969) to group anaerobic, Gram-negative diplococci from the alimentary tract of a pig, previously reported by Fuller (1966). Amino acids, mainly glutamic acid are used as the sole energy source for growth. This genus comprises the type species Acidaminococcus fermentans. Further emendation of the description of the genus Acidaminococcus and its type species was proposed by Cook et al. (1994), which demonstrated that these bacteria can also utilize citrate as an energy source and are able to produce hydrogen and hydrogen sulfide. The genus Acidaminococcus was shown to

Abbreviations: EM, electron microscopy; ML, maximum-likelihood; NJ, neighbour-joining.

The GenBank/EMBL/DDBJ accession numbers for the $16 \mathrm{~S}$ and $23 \mathrm{~S}$ rRNA gene sequences of strain ADV $255.99^{\top}$ are AF473835 and EF060100, respectively.

PFGE migration of I-Ceul-restricted DNAs and EM of cells of strain ADV $255.99^{\top}$ are available as supplementary figures with the online version of this paper. belong to the family 'Acidaminococcaceae', formerly Sporomusa sub-branch, in the phylum Firmicutes (Both et al., 1992; Willems \& Collins, 1995; Garrity \& Holt, 2001).

The 11 clinical strains studied are presented in Table 1. They were isolated over an 8-year-period from various samples collected from 11 patients hospitalized in two geographically distant French hospitals; the University Hospital of Montpellier, South of France and the University Hospital of Nancy, East of France. All strains were recovered from mixed cultures. Strains were grown at $37^{\circ} \mathrm{C}$ on Columbia sheep blood agar for $2-5$ days in an anaerobic jar using the Anaerogen System (Oxoid). Among them, the isolate ADV $255.99^{\mathrm{T}}$ was previously analysed for a phylogenetic reconstruction of the family 'Acidaminococcaceae' (Marchandin et al., 2003a) and an almostcomplete 16S rRNA gene sequence was deposited in the GenBank database under the accession number AF473835. From both phylogenetic analysis and level of sequence similarity with $A$. fermentans $(95.8 \%)$, this strain represents a novel species of the genus Acidaminococcus 
Table 1. Clinical strains of Acidaminococcus intestini sp. nov. used in this study

Strains labelled 'ADV' were from University Hospital Arnaud de Villeneuve, Montpellier, France; strains labelled 'LBN' were from Bacteriology Laboratory of Nancy Hospital, France.

\begin{tabular}{|lccl|}
\hline Strain & $\begin{array}{c}\text { Date of isolation } \\
\text { (month/year) }\end{array}$ & $\begin{array}{c}\text { Age (years)/ } \\
\text { sex of patient }\end{array}$ & \multicolumn{1}{c|}{ Origin } \\
\hline ADV 255.99 $9^{T_{*}}$ & $06 / 1999$ & $45 / \mathrm{M}$ & Peritoneal fluid \\
ADV 5206.02 & $09 / 2002$ & $88 / \mathrm{M}$ & Rectum \\
ADV 2290.04 & $04 / 2004$ & $75 / \mathrm{M}$ & Abdominal fluid \\
ADV 5199.04 & $06 / 2004$ & $56 / \mathrm{M}$ & Mandible necrosis \\
ADV 1190.04 & $12 / 2004$ & $52 / \mathrm{M}$ & Pressure ulcer (sacrum) \\
LBN 316 & $01 / 2004$ & $23 / \mathrm{M}$ & Anal abscess \\
LBN 317 & $07 / 2002$ & $18 / \mathrm{F}$ & Axillary abscess \\
LBN 318 & $09 / 2001$ & $58 / \mathrm{M}$ & Abdominal fluid \\
LBN 319 & $12 / 2001$ & $41 / \mathrm{M}$ & Abdominal fluid \\
LBN 320 & $03 / 1996$ & $67 / \mathrm{F}$ & Inguinal abscess \\
LBN 321 & $02 / 1999$ & $71 / \mathrm{M}$ & Infected parietal haematoma \\
\end{tabular}

${ }^{\star}$ A. intestini ADV $255.99^{\mathrm{T}}\left(=\mathrm{AIP} 283.01^{\mathrm{T}}=\mathrm{CIP} 108586^{\mathrm{T}}=\mathrm{CCUG} 50930^{\mathrm{T}}\right)$.

(Marchandin et al., 2003a). The 11 strains were subjected to polyphasic investigations, to compare with four $A$. fermentans strains, including $A$. fermentans type strain CIP $106432^{\mathrm{T}}\left(=\mathrm{DSM} 20731^{\mathrm{T}}=\right.$ ATCC $25085^{\mathrm{T}}=$ CCUG $\left.9996^{\mathrm{T}}\right)$ and three clinical isolates from our collection, strains ADV 2297.03, ADV 6092.03 and ADV 1338.05. Identified as $A$. fermentans by sequencing $600 \mathrm{bp}$ in the $5^{\prime}$-part of the $16 \mathrm{~S}$ rRNA gene; these three strains displayed 16S rRNA gene sequence similarity levels above $99.5 \%$ with the $A$. fermentans type strain.

DNAs were rapidly extracted by a boiling-freezing method and 16S rRNA gene was selectively amplified by PCR using primers $27 \mathrm{f}$ and $1492 \mathrm{r}$ as described previously (Carlier et al., 2002). The 5 '-part of the $23 \mathrm{~S}$ rRNA gene was amplified using universal primers 6 and 10 as described previously (Anthony et al., 2000). The PCR products were directly sequenced with forward and reverse primers using an Applied Biosystems Automated Sequencer (Genome Express). The sequences were compared with known sequences in the GenBank and EMBL databases using the BLAST program (Altschul et al., 1997) and the LALIGN software (www.expasy.org). The GenBank accession numbers for the 16S rRNA gene sequences are given in Fig. 1 and those for the 23S rRNA gene partial sequences of about 320 bp are EF060094-EF060103. Despite several attempts, $23 \mathrm{~S}$ rRNA gene sequences could not be determined for the A. fermentans type strain and strain ADV 6092.03. The 11 clinical isolates formed a very tight group since they displayed at least 99.9 and $99.7 \%$ identity in the $16 \mathrm{~S}$ and 23S rRNA gene sequences, respectively. The clinical isolates were most closely related to $A$. fermentans but $16 \mathrm{~S}$ rRNA gene similarity level of about $95.6 \%$ indicated that the isolates did not belong to this species. Their $23 \mathrm{~S}$ rRNA gene sequences displayed less than $88.9 \%$ similarity with those of A. fermentans strain ADV 2297.03 (EF060093) and ADV
1338.05 (EF060092), confirming that they might represent a novel species.

The 16S rRNA gene sequences (1365 nt) were aligned against sequences of representative strains and clones retrieved in the GenBank database using the DIALIGN program (Morgenstern, 2002). An evolutionary tree based on the 16S rRNA sequences was inferred using the maximumlikelihood (ML) (Olsen et al., 1994), maximum-parsimony (Kluge \& Farris, 1969) and neighbour-joining (NJ) (Saitou \& Nei, 1987) methods from the PHYLIP suite of programs (Felsenstein, 1993). The algorithm F84 (Kishino \& Hasegawa, 1989) was used to generate evolutionary distance matrices for the NJ method. The robustness of the trees was evaluated by bootstrap analysis of 100 resamplings using the SEQBOOT and CONSENSE programs from the PHYLIP package (Felsenstein, 1993). Regardless of the method used, the reconstructed trees were congruent and the strains formed a statistically well supported lineage, related but distinct from that of A. fermentans (Fig. 1). From sequence analysis and phylogeny, the strains studied can be considered to belong to a novel species of the genus Acidaminococcus, for which the name Acidaminococcus intestini sp. nov. is proposed.

Genomic studies included DNA G $+\mathrm{C}$ content determination and large-scale chromosome structure analysis. The DNA G $+\mathrm{C}$ content, determined by HPLC at the Identification Service of the Deutsche Sammlung von Mikroorganismen und Zellkulturen (Braunschweig, Germany), for strain ADV $255.99^{\mathrm{T}}$ was 49.3 mol\% (Table 2). Number and size of bacterial chromosomes were analysed by PFGE of intact DNAs as described previously (Marchandin et al., 2001) and mapping experiments with the intron-encoded endonuclease I-CeuI (New England Biolabs) were undertaken to determine the rrn skeletons, as described 


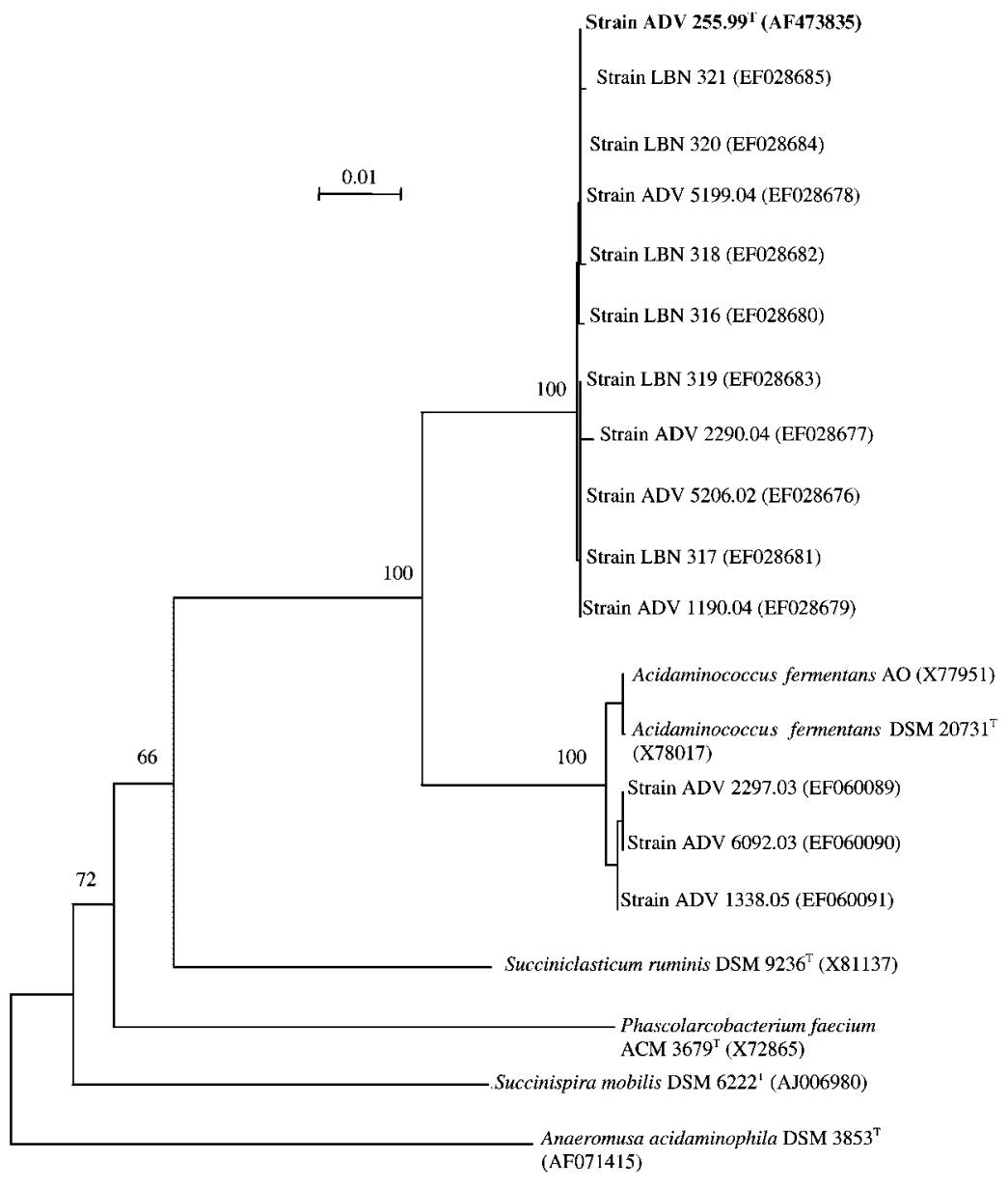

Fig. 1. NJ phylogenetic tree based on partial 16S rRNA gene sequences (1365 nt). Anaeromusa acidaminophila was used as the outgroup. Bootstrap values are indicated at corresponding nodes. GenBank sequence accession numbers are shown in parentheses. Bar, 0.01 substitutions per site.

previously (Marchandin et al., 2003a, b; Teyssier et al., 2003). The rrn skeleton was previously recognized as a sensitive indicator of phylogenetic relationships between bacteria, including members of the family 'Acidaminococcaceae' (Liu et al., 1999; Marchandin et al., 2003a; Jumas-Bilak et al., 2005). Although all the strains studied displayed a similar genomic size of about $2.49 \mathrm{Mb}$ $( \pm 140 \mathrm{~kb})$, the $\mathrm{rrn}$ skeleton clearly distinguished two groups of strains. Indeed, six rrn operon copies could be demonstrated on the chromosome of $A$. fermentans $(n=3)$, whereas the 11 A. intestini isolates possessed three $r r n$ copies (Table 2) (Supplementary Fig. S1 available in IJSEM Online).

Colonies of A. intestini grew on Columbia sheep blood agar plates after 2 days incubation. The colonies were about $0.3-0.5 \mathrm{~mm}$ in diameter, circular, convex, whitish with a smooth surface, non-pigmented and non-haemolytic. The cells were coccoid, smaller than cells of $A$. fermentans type strain, usually occurring as single cells but sometimes in pairs [Supplementary Fig. S2(a) and (b) available in IJSEM Online], Gram-negative after staining, non-spore-forming and non-motile. Cells were prepared as described previously for both negative staining and ultrathin sections (Marchandin et al., 2003a; Jumas-Bilak et al., 2005) and samples were observed under a Hitachi H7100 electron microscope. Cell size was 500-600 $\mathrm{nm}$ in diameter [Supplementary Fig. S2(a) and (b) available in IJSEM Online]. As reported by Rogosa (1969) for the type species of the genus Acidaminococcus, an outer cell wall membrane was observed in thin sections of cells for strain ADV $255.99^{\mathrm{T}}$ by EM [Supplementary Fig. S2(c) available in IJSEM Online].

The strains were identified according to the procedures of the VPI Anaerobe Laboratory Manual (Holdeman et al., 1977). For gas formation detection, cultures were observed for areas of disruption in loosely covered TGY deep agar and for gas bubbles in TGY broth. Special potency discs were used as described by Jousimies-Somer et al. (2002). An API Rapid ID 32A kit (bioMérieux) was used for enzymic profile determination as recommended by the manufacturer. Metabolic end products were assayed by quantitative GC as described previously (Carlier, 1985). Results are listed in Table 2. Strain ADV $255.99^{\mathrm{T}}$ showed the following negative characteristics: catalase, oxidase and urease activities, indole production, nitrate reduction, lactate fermentation, gelatin liquefaction, milk modification and aesculin hydrolysis. Acid was not produced from glucose, lactose, maltose, mannose or sucrose. Gas bubbles were noted in broth cultures. Glutamate was used as an energy source. By presumptive identification tests, the 
Table 2. Phenotypic and genotypic characteristics that differentiate Acidaminococcus intestini sp. nov. from A. fermentans

The following characteristics were common to A. intestini sp. nov. and A. fermentans: resistance to vancomycin discs (5 $\mu$ ), susceptibility to metronidazole $(4 \mu \mathrm{g})$ and colistin $(10 \mu \mathrm{g})$ discs, gas production, glutamate fermentation and absence of lactate fermentation. + , Positive; - , negative.

\begin{tabular}{|c|c|c|}
\hline Characteristic & A. fermentans CIP $106432^{\mathrm{T}_{\star}}$ & A. intestini $(n=11)$ \\
\hline Cell size $(\mu \mathrm{m})$ & $0.6-1.0$ & $0.5-0.6$ \\
\hline Cell morphology & Coccoid, oval or kidney shaped diplococci & Coccoid single cells or pairs \\
\hline Kanamycin (1 mg) & S & $\mathrm{S}(10 / 11)$ \\
\hline Bile $(1 \mathrm{mg})$ & S & $S(8 / 11)$ \\
\hline Ability to ferment carbohydrates & $-\dagger$ & - \\
\hline \multicolumn{3}{|l|}{ API Rapid ID 32A kit: } \\
\hline Code for type strain of the species $\ddagger$ & 0000012401 & 0000016401 \\
\hline Pyroglutamic acid arylamidase activity & - & $+(10 / 11)$ \\
\hline Leucyl glycine arylamidase activity & - & $+(7 / 11)$ \\
\hline Metabolic end products $\S$ & $\mathrm{A}, \mathrm{B}$ & $\mathrm{A}, \mathrm{P}, \mathrm{B},(\mathrm{L})$ (trace amounts $2-\mathrm{OH}-\mathrm{B}, 2-\mathrm{OH}-\mathrm{V}$ ) \\
\hline DNA G $+\mathrm{C}$ content $(\mathrm{mol} \%) \|$ & $56(\mathrm{Bd})$ & $49.3\left(T_{\mathrm{m}}\right)$ \\
\hline
\end{tabular}

* A. fermentans CIP $106432^{\mathrm{T}}$. Data for A. fermentans type strain are from Rogosa $(1969,1984)$ or from this study. A. fermentans strains ADV 2297.03, ADV 6092.03 and ADV 1338.05 were similar to the type strain tested for phenotypic characteristics (morphology, susceptibility profile to special potency discs and enzymic activities on API Rapid ID 32A kit).

$\dagger$ About $40 \%$ of $A$. fermentans strains catabolize glucose and the reaction is weak (Rogosa, 1969).

$\ddagger$ A. fermentans CIP $106432^{\mathrm{T}}$ showed the following activities: arginine arylamidase, leucine arylamidase, glycine arylamidase and histidine arylamidase. A. intestini ADV $255.99^{\mathrm{T}}\left(=\right.$ AIP $283.01^{\mathrm{T}}=$ CIP $108586^{\mathrm{T}}=$ CCUG $\left.50930^{\mathrm{T}}\right)$ showed, in addition, pyroglutamic acid arylamidase $($ PyrA) activity. With the exception of strain LBN 321, which showed a poor profile in the API Rapid ID 32A identification panel (only two positive reactions: indole and PyrA), two activities were variable among A. intestini strains: leucyl glycine arylamidase and PyrA activities.

$\$$ A, Acetic acid; B, butyric acid; P, propionic acid; L, lactic acid; 2-OH-B, 2-hydroxybutyric acid; 2-OH-V, 2-hydroxyvaleric acid. Parentheses indicate that these compounds are produced in variable amounts.

IIA. fermentans, values determined for 14 strains by Rogosa (1969) ranged from 55.6 to $57.4 \mathrm{~mol} \%$; A. intestini, determined for type strain ADV $255.99^{\mathrm{T}}$.

S. fermentans strains ADV 2297.03, ADV 6092.03 showed similar genomic structure to A. fermentans CIP $106432^{\mathrm{T}}$ (data available as Supplementary Fig. S2 in IJSEM Online) and their genomic sizes were estimated to be 2.49 and $2.55 \mathrm{Mb}$, respectively. Genomic size for A. intestini $(n=11)$ ranged from 2.40 to $2.62 \mathrm{Mb}$ (mean size, $2.49 \mathrm{Mb}$ ); A. intestini ADV $255.99^{\mathrm{T}}$ chromosome size was estimated to be $2.43 \mathrm{Mb}$.

strain was resistant to $5 \mu \mathrm{g}$ vancomycin disc and susceptible to $1 \mathrm{mg}$ kanamycin, $10 \mu \mathrm{g}$ colistin, $4 \mu \mathrm{g}$ metronidazole and $1 \mathrm{mg}$ bile discs. The enzymic profile determined using the API Rapid ID 32A system gave the following code 0000016410 corresponding to arginine, leucine, pyroglutamic acid, glycine and histidine arylamidase activities. The metabolic end products were acetate $\left(32.3 \mathrm{mmol} \mathrm{l}^{-1}\right)$, butyrate $\left(14.3 \mathrm{mmol} \mathrm{l}^{-1}\right)$ and propionate $\left(3.4 \mathrm{mmol} \mathrm{l}^{-1}\right)$. Some characteristics of the type strain were found to be variable among $A$. intestini strains, in particular indole production, susceptibility to special potency discs, enzymic activities and metabolic end products (Table 2). Indeed, lactic acid was produced by four of the $11 \mathrm{~A}$. intestini strains $\left(3.5-4.5 \mathrm{mmol} \mathrm{l}^{-1}\right)$ and trace amounts $\left(\leqslant 0.5 \mathrm{mmol} \mathrm{l}^{-1}\right)$ of 2-hydroxybutyric acid, 2-hydroxyvaleric acid and/or isovaleric acid were produced by five strains.

On the basis of phenotypic, genotypic and phylogenetic characteristics, we suggest that the strains studied represent a novel species of the genus Acidaminococcus. The pattern of sites of isolation of these strains (Table 1) resembles that previously observed for A. fermentans in humans (Moore \& Holdeman, 1974; Sugihara et al., 1974; Nakashima et al., 1983; Peraino et al., 1993; Chatterjee \& Chakraborti, 1995; Goldstein et al., 2000; Galán et al., 2000). However, the strains were mainly recovered from samples originating from the gastro-intestinal tract. Moreover, the isolates were related to several uncultured clones and two butyrateproducing strains, all found in human faecal microbiota and showing 99 to $99.8 \% 16 \mathrm{~S}$ rRNA gene sequence similarity with strain $\mathrm{ADV} 255.99^{\mathrm{T}}$ [uncultured clones O14C-G10 (DQ905693), O14C-C7 (DQ905653), O14B-E11 (DQ905592), O14B-B6 (DQ905551), 014B-E8 (DQ905589), O14B-F11 (DQ905603), 014B-B10 (DQ905555), O14C-E10 (DQ905674) and O14B-C12 (DQ905569); butyrate-producing bacteria PH05YA06 (DQ144118) and PH05YA07 (DQ144119)].

The name Acidaminococcus intestini sp. nov. is proposed for the strains analysed in this study. 


\section{Emended description of the genus Acidamino- coccus Rogosa 1969 emend. Cook et al. 1994}

The description is as emended by Cook et al. (1994) with the following modifications: cocci $0.5-1 \mu \mathrm{m}$ in diameter occurring as single cells, oval or kidney-shaped diplococci. Propionate may or may not be produced. The DNA G $+\mathrm{C}$ content is $49.3\left(T_{m}\right)$ or $56 \mathrm{~mol} \%(\mathrm{Bd})$. Chromosome size is $4.9 \mathrm{Mb} \pm 6 \%$ and $r r n$ copy number is three or six.

\section{Description of Acidaminococcus intestini sp. nov.}

Acidaminococcus intestini (in.tes.ti.ni. L. gen. n. intestini, of the intestine).

Cells are Gram-negative after staining, non-spore-forming cocci that occur as single cells or in pairs. Individual cells are $0.5-0.6 \mu \mathrm{m}$ in diameter. Colonies on Columbia sheep blood agar after 2 days incubation are about $0.3-0.5 \mathrm{~mm}$ in diameter, circular, convex, whitish with a smooth surface. Non-pigmented and non-haemolytic. Strictly anaerobic. Oxidase- and catalase-negative. Gelatinase and nitrate-reduction tests are negative. Gas bubbles are noted in broth cultures. Indole may be produced. Carbohydrates are not fermented. Lactate is not used and glutamate is fermented. The metabolic end products are acetic acid, butyric acid and propionic acid. Lactic acid may be produced. Trace amounts $\left(\leqslant 0.5 \mathrm{mmol} \mathrm{l}^{-1}\right)$ of 2-hydroxybutyric acid, 2-hydroxyvaleric acid and isovaleric acid may be produced. Habitat is the gastro-intestinal tract of humans. The DNA G + C content of strain ADV $255.99^{\mathrm{T}}$ is $49.3 \mathrm{~mol} \%$.

Can be differentiated from $A$. fermentans by pyroglutamic acid arylamidase activity, metabolic end products, mainly by propionic acid production, $16 \mathrm{~S}$ and $23 \mathrm{~S}$ rRNA gene sequencing, DNA G $+\mathrm{C}$ content, and $r r n$ skeleton.

The type strain, ADV $255.99^{\mathrm{T}}\left(=\right.$ AIP $283.01^{\mathrm{T}}=\mathrm{CIP}$ $108586^{\mathrm{T}}=$ CCUG $50930^{\mathrm{T}}$ ), was isolated from human clinical specimens.

\section{Acknowledgements}

We are indebted to C. Bizet and D. Clermont from the Collection de l'Institut Pasteur for providing us the type strain of A. fermentans. We thank I. Zorgniotto, R. Devine and M. Chaon for excellent technical assistance. This work is partly supported by the association ADEREMPHA, Montpellier, France.

\section{References}

Altschul, S. F., Madden, T. L., Schaffer, A. A., Zhang, J., Zhang, Z., Miller, W. \& Lipman, D. J. (1997). Gapped BLAST and PSI-BLAST: a new generation of protein database search programs. Nucleic Acids Res 25, 3389-3402.

Anthony, R. M., Brown, T. J. \& French, G. L. (2000). Rapid diagnosis of bacteremia by universal amplification of $23 \mathrm{~S}$ ribosomal DNA followed by hybridization to an oligonucleotide array. $J$ Clin Microbiol 38, 781-788.
Both, B., Buckel, W., Kroppenstedt, R. \& Stackebrandt, E. (1992). Phylogenetic and chemotaxonomic characterization of Acidaminococcus fermentans. FEMS Microbiol Lett 76, 7-11.

Carlier, J.-P. (1985). Gas chromatography of fermentation products: its application in diagnosis of anaerobic bacteria. Bull Inst Pasteur 83, 57-69.

Carlier, J.-P., Marchandin, H., Jumas-Bilak, E., Lorin, V., Henry, C., Carrière, C. \& Jean-Pierre, H. (2002). Anaeroglobus geminatus gen. nov., sp. nov., a novel member of the family Veillonellaceae. Int J Syst Evol Microbiol 52, 983-986.

Chatterjee, B. D. \& Chakraborti, C. K. (1995). Non-sporing anaerobes in certain surgical group of patients. J Indian Med Assoc 93, 333-339.

Cook, G. M., Rainey, F. A., Chen, G., Stackebrandt, E. \& Russell, J. B. (1994). Emendation of the description of Acidaminococcus fermentans, a trans-aconitate- and citrate-oxidizing bacterium. Int J Syst Bacteriol 44, 576-578.

Felsenstein, J. (1993). PHYLIP (phylogeny inference package), version 3.5c. Distributed by the author. Department of Genome Sciences, University of Washington, Seattle, USA.

Fuller, R. (1966). Some morphological and physiological characteristics of gram-negative anaerobic bacteria isolated from the alimentary tract of the pig. J Appl Bacteriol 29, 375-379.

Galán, J. C., Reig, M., Navas, A., Baquero, F. \& Blázquez, J. (2000). ACI-1 from Acidaminococcus fermentans: characterization of the first $\beta$-lactamase in anaerobic cocci. Antimicrob Agents Chemother 44, 3144-3149.

Garrity, G. M. \& Holt, J. G. (2001). Taxonomic outline of the Archaea and Bacteria. In Bergey's Manual of Systematic Bacteriology, 2nd edn, vol. 1, pp. 155-166. Edited by D. R. Boone \& R. W. Castenholz. New York: Springer.

Goldstein, E. J., Citron, D. M., Vreni Merriam, C., Warren, Y. \& Tyrrell, K. L. (2000). Comparative in vitro activities of ertapenem (MK-0826) against 1,001 anaerobes isolated from human intra-abdominal infections. Antimicrob Agents Chemother 44, 2389-2394.

Holdeman, L. V., Cato, E. P. \& Moore, W. E. C. (1977). Anaerobe Laboratory Manual, 4th edn. Blacksburg, VA: Virginia Polytechnic Institute and State University.

Jousimies-Somer, H. R., Summanen, P., Citron, D. M., Baron, E. J., Wexler, H. M. \& Finegold, S. M. (2002). Wadworth-KTL Anaerobic Bacteriology Manual, 6th edn. Belmont, CA: Star Publishing Company.

Jumas-Bilak, E., Jean-Pierre, H., Carlier, J.-P., Teyssier, C., Bernard, K., Gay, B., Campos, J., Morio, F. \& Marchandin, H. (2005). Dialister micraerophilus sp. nov. and Dialister propionicifaciens sp. nov., isolated from human clinical samples. Int J Syst Evol Microbiol 55, 2471-2478.

Kishino, H. \& Hasegawa, M. (1989). Evaluation of the maximum likelihood estimate of the evolutionary tree topologies from DNA sequence data, and the branching order in Hominoidea. J Mol Evol 29, $170-179$.

Kluge, A. \& Farris, J. (1969). Quantitative phyletics and the evolution of anurans. Syst Zool 18, 1-32.

Liu, S.-L., Schryvers, A. B., Sanderson, K. E. \& Johnston, R. N. (1999). Bacterial phylogenetic clusters revealed by genome structure. $J$ Bacteriol 181, 6747-6755.

Marchandin, H., Jean-Pierre, H., Carrière, C., Canovas, F., Darbas, H. \& Jumas-Bilak, E. (2001). Prosthetic joint infection due to Veillonella dispar. Eur J Clin Microbiol Infect Dis 20, 340-342.

Marchandin, H., Jumas-Bilak, E., Gay, B., Teyssier, C., Jean-Pierre, H., Siméon de Buochberg, M., Carrière, C. \& Carlier, J.-P. (2003a). Phylogenetic analysis of some Sporomusa sub-branch members 
isolated from human clinical specimens: description of Megasphaera micronuciformis sp nov. Int J Syst Evol Microbiol 53, 547-553.

Marchandin, H., Teyssier, C., Siméon de Buochberg, M., JeanPierre, H., Carrière, C. \& Jumas-Bilak, E. (2003b). Intrachromosomal heterogeneity between the four $16 \mathrm{~S}$ rRNA gene copies in the genus Veillonella: implications for phylogeny and taxonomy. Microbiology 149, 1493-1501.

Moore, W. E. C. \& Holdeman, L. V. (1974). Human fecal flora: the normal flora of 20 Japanese-Hawaiians. Appl Microbiol 27, 961-979.

Morgenstern, B. (2002). A simple and space-efficient fragmentchaining algorithm for alignment of DNA and protein sequences. Appl Math Lett 15, 11-16.

Nakashima, M., Ikoma, H., Yokoyama, M., Suzuki, T. \& Sugihara, S. (1983). Cefotiam passage into the maxillary sinus tissues. Jpn J Antibiot 36, 2730-2732.

Olsen, G. J., Matsuda, H., Hagstrom, R. \& Overbeek, R. (1994). fastDNAml: a tool for construction of phylogenetic trees of DNA sequences using maximum likelihood. Comput Appl Biosci 10, 41-48.

Peraino, V. A., Cross, S. A. \& Goldstein, E. J. C. (1993). Incidence and significance of anaerobic bacteremia in a community hospital. Clin Infect Dis 16, S288-S291.
Rogosa, M. (1969). Acidaminococcus gen. n., Acidaminococcus fermentans sp. n., anaerobic Gram-negative diplococci using amino acids as the sole energy source for growth. J Bacteriol 98, 756-766.

Rogosa, M. (1984). Anaerobic Gram-negative cocci. In Bergey's Manual of Systematic Bacteriology, vol. 1, pp. 680-685. Edited by N. R. Krieg \& J. G. Holt. Baltimore: Williams \& Wilkins.

Saitou, N. \& Nei, M. (1987). The neighbor-joining method: a new method for reconstructing phylogenetic trees. Mol Biol Evol 4, 406-425.

Sugihara, P. T., Sutter, V. L., Attebery, H. R., Bricknell, K. S. \& Finegold, S. M. (1974). Isolation of Acidaminococcus fermentans and Megasphaera elsdenii from normal human feces. Appl Microbiol 27, 274-275.

Teyssier, C., Marchandin, H., Siméon de Buochberg, M., Ramuz, M. \& Jumas-Bilak, E. (2003). Atypical 16S rRNA gene copies in Ochrobactrum intermedium strains reveal a large genomic rearrangement by recombination between rrn copies. J Bacteriol 185, 2901-2909.

Willems, A. \& Collins, M. D. (1995). Phylogenetic placement of Dialister pneumosintes (formerly Bacteroides pneumosintes) within the Sporomusa subbranch of the Clostridium subphylum of the grampositive bacteria. Int J Syst Bacteriol 45, 403-405. 